\title{
Saltwater spawning grounds of sea-run brown trout (Salmo trutta) in tidal waters of a major Norwegian river
}

\author{
Sven-Erik Gabrielsen • Robert J. Lennox • \\ Tore Wiers · Bjørn T. Barlaup
}

Received: 26 December 2020 / Accepted: 7 September 2021 / Published online: 27 September 2021

(C) The Author(s) 2021

\begin{abstract}
Sea-run brown trout (Salmo trutta) have a highly phenotypically plastic life history that allows them to be effective colonizers and competitors in freshwater. This paper documents a previously unknown spawning behaviour in a brackish, tidally influenced estuary $14 \mathrm{~km}$ from the mouth of the Vosso River, a major Atlantic salmon- and searun brown trout-producing river in western Norway. Putative spawning gravel was observed, and sea-run brown trout deposited eggs that hatched in April. Survival of recruits was high $(>95 \%)$ in the tidal spawning gravel. These areas are strongly tidally influenced with a peak of 23.17 psu recorded at the lowest spawning ground. The observation of spawning so far from the river mouth may be unique in such a system with a long estuary but provides important insight into the biology of sea trout. Invasion of pink salmon, also known to spawn in estuaries, may negatively affect the competitive balance of sea trout with other salmonids in rivers where sea trout populations rely on recruitment from these relatively extreme spawning areas. Restoration of estuaries that have been modified by dredging or channelization may be important to ensure quality and heterogenous habitat
\end{abstract}

S.-E. Gabrielsen $(\bowtie) \cdot$ R. J. Lennox · T. Wiers ·

B. T. Barlaup

Laboratory for Freshwater Ecology and Inland Fisheries (LFI), NORCE Norwegian Research Centre,

Nygårdsporten 112, 5006 Bergen, Norway

e-mail:svga@norceresearch.no for sea trout spawning given that haline spawning grounds could contribute to population resilience.

Keywords Haline $\cdot$ Marine $\cdot$ Estuary · Reproduction $\cdot$ Evolution $\cdot$ Ecology

\section{Introduction}

Brown trout, Salmo trutta L., has a well-studied partially migratory life history that can take them from their freshwater spawning streams into the ocean to feed and grow (i.e. sea-run brown trout) (Klemetsen et al. 2003). Most sea-run brown trout live 1-3 years in fresh water and then may undergo a physiological change, smoltification, which guides them to the ocean (Jonsson 1985; Titus and Mosegaard 1992). In Norway, the mean smolt age increases significantly with latitude, a consequence of the shorter seasons for growth in the north (L'Abée-Lund et al. 1989). Once at sea, trout generally spend a few weeks or months in the upper surface layers of coastal zones feeding predominantly on benthic invertebrates and other fish (Davidsen et al. 2017). Trout then return to freshwater to overwinter or spawn and will generally return to the sea the following spring or summer (Klemetsen et al. 2003). Migratory movement between fresh and saltwater is regulated by osmoregulatory organs and enzymes that facilitate the transition between environments that not all fish can cope with. 
Sea-run brown trout are especially recognized for the plasticity that they display in their life history (e.g. Peiman et al. 2017). Trout may mature without migrating or spend long periods at sea before returning to spawn (Klemetsen et al. 2003). Travel between freshwater and the marine environment is not uncommon and may be an adaptation of the fish to get rid of marine parasites (Gjelland et al. 2014). Trout are also observed exiting freshwater in small streams exposed to drought and have been observed moving to the Baltic Sea even before the physiological initiation of smoltification (Landergren and Vallin 1998). Whether trout can make use of saline habitats for spawning production is less clear. Landergren and Vallin (1998) found that fertilization was possible at $6.7 \mathrm{psu}$, salinities characteristic of the waters around the Baltic island of Gotland, but the ensuing development of eggs was inhibited at salinities exceeding 4.0 psu. No hatching was observed in ambient Baltic Sea water, and recruitment to the sea trout population from this area was regarded as null. Further, Rubin (1994) investigated egg-to-fry survival of sea trout eggs in various salinities, finding only a minor difference $(11 \%)$ of this survival between freshwater and Baltic Sea water. However, these results were experimental, and eggs were fertilized in freshwater and transferred to brackish water for hatching. No direct evidence of trout spawning in saline waters have yet been revealed.

Despite there being no reports of survival of sea trout eggs and fry from naturally buried eggs in areas with brackish water, saline areas in estuaries may add additional spawning areas for sea-run brown trout. If sea-run brown trout can spawn in saline waters, the total production of a catchment will be the sum of spawning potential in the main river and tributaries, as well as the estuary, and assessments must be cognizant of production beyond freshwater when making management decisions. The availability of potential estuarine spawning areas might buffer sea trout populations from drought or pollution in rivers and attenuate competition with other species such as Atlantic salmon that cannot use these areas for spawning. This study outlines and describes observations of sea-run brown trout spawning in brackish water $14 \mathrm{~km}$ from the outlet of Vosso River, a major river in western Norway with substantial potential freshwater available for spawning.

\section{Materials and methods}

\section{Study area}

The putative spawning grounds were surveyed in an intertidal zone approximately $14 \mathrm{~km}$ from the outlet of Vosso River, western Norway (Fig. 1). Four separate spawning grounds were located in a range of $900 \mathrm{~m}$ in the intertidal zone between Bolstad and Vikafjorden. The two largest spawning grounds were closely investigated. The physical conditions in the intertidal zone where the spawning area was surveyed were strongly influenced by tidal water; thus salinity, water velocity, and temperature change every 6 h. According to Bjerkenes et al. (1998), the water velocity out of the fjord fluctuated from a minimum of $1.1 \mathrm{~cm} / \mathrm{s}$ to a maximum of $112.4 \mathrm{~cm} / \mathrm{s}$ with a mean of $50 \mathrm{~cm} / \mathrm{s}$. Salinity changed from a minimum of 0.56 psu to a maximum of $19.5 \mathrm{psu}$ with a mean of $4.0 \mathrm{psu}$ in this period. The temperature was found to change from 1.4 to $4.8{ }^{\circ} \mathrm{C}$ with a mean of $2.5{ }^{\circ} \mathrm{C}$. The highest salinity and temperature were associated with an incoming tide, while the highest water velocity was associated with an outgoing tide. The spawning grounds are therefore situated in an area that can be described as a tidal stream.

Individual nests were located by wading and by digging in the gravel by a pointed shovel (Fig. 2). A subsample of eggs from each nest was captured in a net with a $250-\mu \mathrm{m}$ mesh size. Eggs were identified to species by genetic analysis (Mork and Heggberget 1984; Vuorinen and Piironen 1984). From each nest, the following data were recorded: egg survival (number of live eggs vs. dead eggs), water depth (distance from gravel surface to water surface), and burial depth (distance from gravel surface to top of egg pocket). The mean egg survival was calculated for all sampled nests. Sampling was done in 2002 at five dates: March 12, April 16, May 10, May 31, and June 19 and on May 19 and May 21 in 2003 and May 24, 2004.

Measurements of salinity (psu), temperature, oxygen, and density

A STD/CTD model SD204 was used to measure, calculate, and record salinity and temperature every $10 \mathrm{~min}$. The device was put on the upper marine 
Fig. 1 Map of the Vosso River system and Bolstadfjord. The Vosso River discharges into the Bolstadfjord. The Bolstadfjord extends $16 \mathrm{~km}$ to the Veafjord, an arm of the Osterfjord system. The fjord spawning site of the sea trout (Salmo trutta) is marked where redd surveys were conducted

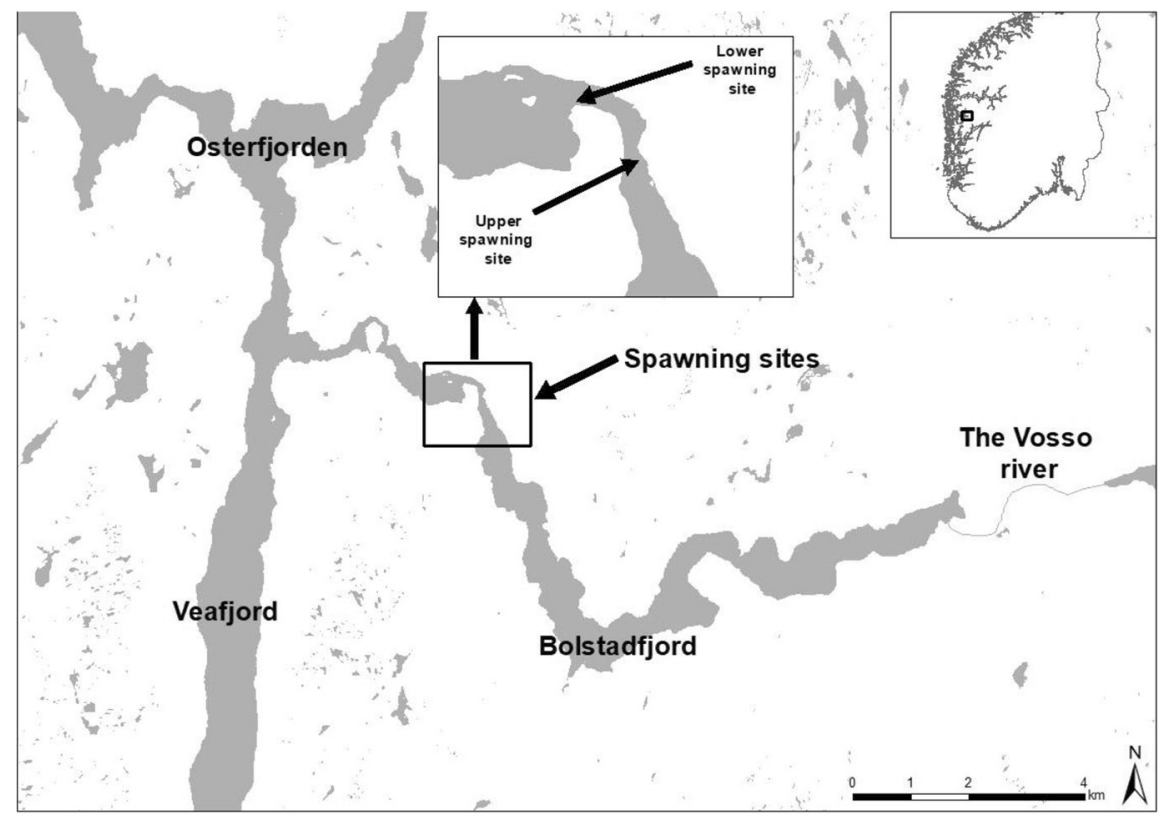

spawning area from March 22, 2002, to May 2, 2002, and on the lowest spawning area from May 28, 2003, to June 14, 2004. Interstitial oxygen was measured with a Therune standpipe at fourteen sites in the upper marine spawning ground in March 2002.

\section{Results}

Egg deposition

The mean burial depth of eggs found in the present study was $9.4 \mathrm{~cm}(S D=3.6)$. The deepest nest was situated $18 \mathrm{~cm}$ beneath the gravel surface, whereas the shallowest was located $4 \mathrm{~cm}$ under the gravel surface. In 2002, when burial depth was measured throughout the spring, nests found in March were located deeper from the gravel surface compared to nests found in May (this may have been sampling bias such that eggs had hatched and yolk-sac fry had moved upwards in the gravel by May). In March, the nests contained only eggs, whereas all nests in May consisted of YSA. The classification of gravel and cobbles that constitute the egg pockets according to Wentworth classification had a mean of 8.2 $(S D=0.4)$. This means an average size of gravel from 3.2 to $6.4 \mathrm{~cm}$.
Following observations of spawning in the fjord gravel, salinity was measured at the sites in subsequent years. Salinity fluctuated at both the upper and lower spawning sites. The highest measured salinity on the upper spawning area was 9.73 psu at high tide (13:39:43) on April 1, 2002, compared to the highest measured salinity on the lower spawning area which was 23.17 psu at high tide (21:21:00) on December 1, 2002. Daily salinity fluctuates tidally; for example, in 10 min from 02:09 PM to 02:19 PM on April 1, 2002, the salinity changed from 8.8 to 0.53 psu on the upper spawning area. No egg pockets were anoxic. Interstitial oxygen within redds was found to be $11.4 \mathrm{mg} / \mathrm{l}$ $(S D=0.3 ; \min =11, \max =12.4)$.

\section{Survival of recruits}

The survival of recruits, defined as both eggs and yolk-sac alevins (YSA) that remain in nests, is generally high (i.e. $>95 \%$ ) and suggests normal conditions for survival of juvenile trout. A total of 131 nests were sampled from 2002 to 2004 with a mean number of 14.2 to 27.0 recruits (eggs and/or fry) examined per nest (Table 1). Survival ranged from zero to $100 \%$ with a mean of $96.3 \%(S D=12.5)$ in the two marine spawning grounds surveyed. 



Fig. 2 Sea-run brown trout (Salmo trutta) nests in the gravel substratum in the marine spawning areas, shown at low tide. The first image shows the Straume Bridge in the Bolstadfjord, $14 \mathrm{~km}$ from the mouth of the Vosso River. The second photograph shows a redd depression where sea-run brown trout have spawned in the fjord gravel in the tidal stream

Table 1 The number of nests, the mean number of eggs or yolk-sac alevins (recruits) examined per nest, and the mean recruit survival per nest. Standard deviation is noted as SD.
Egg development

On March 12, 2002, only eggs were found, whereas on April 16, 2002, only two out of 20 nests held eggs, with the remainder having YSA. On April 16, all the YSA were clumped and gave signs of being recently hatched, some still getting rid of the eggshell. From May 10, 2002, all the nests examined held YSA. The approximate hatching period has most likely been in the beginning of April, close to April 15. In 2003 and 2004, the eggs had already developed to the YSA stage by the time of observation in the middle of May.

\section{Discussion}

We observed that sea-run brown trout dug redds in the estuarine gravel, fertilized eggs, and hatched fry the following year. Both shallow and deep redds were measured, and eggs observed were found to hatch with high success comparable to what is observed in full freshwater. As a tidally influenced area more than $10 \mathrm{~km}$ from the river mouth, salinity fluctuated throughout the day, and we hypothesize that trout were synchronizing spawning with the efflux of saltwater at low tide. This research shows the first example of Salmo trutta spawning successfully in saline water, following observations by Limburg et al. (2001) that spawning occurred in salinities up to 5 psu. Our observations of egg deposition and development in saltwater for multiple years suggest that this species can consistently exploit the coastal marine

Measurements on the upper and lower marine spawning grounds surveyed are noted for surveys 2002-2004

\begin{tabular}{lllll}
\hline Date & Marine spawning site & Number of nests sampled & $\begin{array}{l}\text { Mean number of recruits per } \\
\text { nest }(S D)\end{array}$ & $\begin{array}{l}\text { Mean recruit } \\
\text { survival }(\%) \\
(S D)\end{array}$ \\
\hline March 12, 2002 & Upper & 35 & $17.5(8.1)$ & $97.7(8.2)$ \\
April 16, 2002* & Upper & 20 & $27.0(1.4)$ & $100(0.0)$ \\
May 10, 2002 & Upper & 19 & $14.7(9.2)$ & $99.8(0.8)$ \\
May 31, 2002 & Upper & 16 & $20.8(20.4)$ & $99.1(3.6)$ \\
May 19, 2003 & Upper & 11 & $14.2(3.0)$ & $98.5(3.6)$ \\
May 21, 2003** & Lower & 15 & $22.7(10.8)$ & $82.4(27.1)$ \\
May 24, 2004 & Lower & 15 & $14.7(6.5)$ & $97.8(8.6)$ \\
\hline
\end{tabular}

\footnotetext{
${ }^{*}$ The number of egg/yolk-sac alevins was only counted for two egg pockets

** One nest situated close to shore and probably stranded with only dead eggs
} 
environment for spawning production. We made detailed observations of this previously unknown behaviour in only the estuary of the Vosso River, so the generality of this behaviour is unknown. However, the implications and opportunities for further investigation include research on the physiological mechanisms, population dynamics, and community ecology that permits and supports this cryptic behaviour. Estuaries are not traditionally viewed as spawning habitat for sea-run brown trout, and many are modified by dredging or channelization that potentially removes important spawning habitat for trout, which may be a key conservation consideration for this species.

Further research is needed to ascertain the importance of these haline spawning sites to sea-run brown trout populations. In large rivers such as Vosso, it can be expected that eggs deposited in the estuarine environment will represent a minority of the total production from the river but in years of extreme environmental variability may represent an important safeguard for the population. Many salmonids exhibit various strategies to cope with the potential for recruitment failures caused by environmental variation. Iteroparity of Atlantic salmon, for example, has been postulated to provide a contingency against smolt year class failure (Saunders and Schom 1985). The euryhaline biology of sea-run brown trout is already described as an adaptation to cope with unpredictable stream conditions such as drought, with juveniles exiting small streams very soon after hatching or adults moving out after spawning (Limburg et al. 2001; Klemetsen et al. 2003). This behaviour may be specialized in this river, and others like it, with long estuarine areas that have suitable substrate. Female trout dig redds, lay eggs, and bury them in coarse gravel of well-oxygenated areas, mostly rivers but sometimes lakes, and, evidently, estuaries (Klemetsen et al. 2003, this paper). The phenomenon here described may not be replicated in rivers where suitable substrata are not available.

Other salmonids species in the genus Oncorhynchus can spawn in intertidal areas in the lower river sections (Heard 1991; Salo 1991). There are mainly two species using lower river reaches as spawning grounds, Oncorhynchus gorbuscha and O. keta. Decreased survival of egg and alevin from the upper to the lower reaches was explained by higher salinity concentration in the lower section (Salo 1991). Pink salmon (O. gorbuscha) have begun to establish in Norway, particularly in the north (Mo et al. 2018), and this species may compete with sea-run brown trout for the estuarine spawning habitats described in this paper. Sea-run brown trout are known to use estuaries even as fry (Järvi et al. 1996), and these areas are increasingly recognized as crucial for the life history of many salmonids (Levings 2016).

This observation generates new questions about the biology of sea-run brown trout including the genetics and physiology of sea-run brown trout that spawn in the estuarine environment. Based on these observations, it is hypothesized that sea-run brown trout track their spawning with the flood and ebb tides so that eggs are deposited and fertilized when salinity is the lowest. We did not genotype parents or offspring of eggs observed in the estuarine environment and therefore are uncertain about the heritability of the marine spawning phenotype. Moreover, it is unclear whether trout are more likely to spawn in the estuarine environment if competition for space in the river is high, including between conspecifics and between sea-run brown trout and with other native (e.g. Atlantic salmon, Arctic charr) and non-native (e.g. pink salmon) salmonids. Parental salmonids are known to pass on important environmental information to their offspring to prime them for hatching (Sopinka et al. 2014), and perhaps, parents spawning in haline waters will influence the gene expression of their offspring such that they upregulate smoltification. Finally, we ask what the costs and benefits are of spawning in estuaries. We found recruit survival to be high, suggesting that costs are low and benefits may be high if these areas are available and not used by competitors. Detailed investigations of the physiological profiles of estuary spawning trout, demographic and genetic composition of the estuary spawners, and time series observations of recruit survival will reveal more about the adaptivity of this phenotype. Additional experimental studies could be conducted by exchanging eggs between estuary and riverine type spawn to track hatching success and fry behaviour and physiology.

Freshwater inputs into estuaries such as the Bolstadfjord are dynamic throughout the year. Spring floods from rivers will increase freshwater input seasonally, and long-term climatic trends such as drought will also have an impact on salinity levels. Human impacts must also be considered; hydropower generation can withdraw or redirect freshwater input 
in rivers, altering the cycles of freshwater input in a way that affects estuarine salinity. Dredging and other physical alterations to habitat will affect water exchange rates that influence salinity, density, and mixing rates in estuaries and fjords. In the Bolstadfjord, the Vosso River discharges freshwater at the distal end, regulating the salinity of the fjord to some extent. Dredging in the fjord nearby these marine spawning grounds has affected input of marine water from the Osterfjord, and the Evanger power station increases the overall freshwater input to the fjord annually, which has reduced the salinity of the fjord since the installation of the power station in the 1970s. The regulation of the water means that the overall flow dynamics of Vosso and salinity in the Bolstadfjord are fairly stable now, albeit with some annual variation and tidal influence. Future work should focus on understanding how estuary dynamics caused by both climatic and anthropogenic factors affect the stability of these marine spawning areas.

This paper is based on opportunistic observations of spawning places in a long fjord with spawning sediments in tidal water where historic salinity measurements were available. We did not have daily salinity measurements for the time period that the spawning grounds were observed but have no suspicion that the salinity of the ebb and flood tide would have changed dramatically from the period when the observations were made directly. Nevertheless, this is clearly a limitation of the study that we do not have simultaneous or long-term salinity data corresponding directly between the study sites and years; more research is clearly needed to document the spawning behaviour of trout in haline water because of the implications for sea-run brown trout demography, population genetics, resilience to environmental stochasticity, and competition with other species. Our results suggest further fundamental research on the salt tolerance of sea-run brown trout eggs and juveniles and the behaviour of alevins and fry that emerge in saltwater. These data contribute to understanding of the life cycle of searun brown trout and may be used to enhance conservation efforts, for example, restoring gravelled estuaries where spawning could potentially take place if the effects of dredging or channelization were reversed.

Acknowledgements Three anonymous reviewers provided constructive feedback on this manuscript, and we are very grateful for their time and expertise.
Funding Open access funding provided by NORCE Norwegian Research Centre AS.

Data availability Data will be available in the Zenodo data sharing platform.

\section{Declarations}

Ethics approval Ethical approvals were not applicable to the present study.

Conflict of interest The authors declare no competing interests.

Open Access This article is licensed under a Creative Commons Attribution 4.0 International License, which permits use, sharing, adaptation, distribution and reproduction in any medium or format, as long as you give appropriate credit to the original author(s) and the source, provide a link to the Creative Commons licence, and indicate if changes were made. The images or other third party material in this article are included in the article's Creative Commons licence, unless indicated otherwise in a credit line to the material. If material is not included in the article's Creative Commons licence and your intended use is not permitted by statutory regulation or exceeds the permitted use, you will need to obtain permission directly from the copyright holder. To view a copy of this licence, visit http://creativecommons.org/licenses/by/4.0/.

\section{References}

Bjerkens V, Golmen LG, Åtland ̊̊ (1998) Undersøkelse av vannkvalitet og overleving av laksesmolt i Bolstadfjorden. NIVA Report, available at: https://niva.brage.unit.no/nivaxmlui/bitstream/handle/11250/208344/3282_72dpi.pdf? sequence $=1 \&$ is Allowed=y. Accessed 26 Sep 2021

Davidsen JG, Knudsen R, Power M, Sjursen AD, Rønning L, Hårsaker K et al (2017) Trophic niche similarity among sea trout Salmo trutta in central Norway investigated using different time-integrated trophic tracers. Aquat Biol 26:217-227

Gjelland KØ, Serra-Llinares RM, Hedger RD, ArechavalaLopez P, Nilsen R, Finstad B et al (2014) Effects of salmon lice infection on the behaviour of sea trout in the marine phase. Aquacult Environ Int 5:221-233

Heard WR (1991) Life history of pink salmon. Pacific salmon life histories, 119-230

Järvi T, Holmgren K, Rubin JF, Petersson E, Lundberg S, Glimsäter C (1996) Newly-emerged Salmo trutta fry that migrate to the sea-an alternative choice of feeding habit? Nord J Freshw Res 72:52-56

Jonsson B (1985) Life history patterns of freshwater resident and sea-run migrant brown trout in Norway. Trans Am Fish Soc 114:182-194

Klemetsen A, Amundsen PA, Dempson JB, Jonsson B, Jonsson N, O'Connell MF, Mortensen E (2003) Atlantic salmon Salmo salar L., brown trout Salmo trutta L. and Arctic 
charr Salvelinus alpinus (L.): a review of aspects of their life histories. Ecol Freshw Fish 12:1-59

L'Abee-Lund JH, Jonsson B, Jensen AJ, Saettem L, Heggberget TG, Johnsen BO, Naesje TF (1989) Latitudinal variation in life-history characteristics of sea-run migrant brown trout Salmo trutta. J Anim Ecol: 525-542

Landergren P, Vallin L (1998) Spawning of sea trout, Salmo trutta L., in brackish waters-lost effort or successful strategy? Fish Res 35:229-236

Levings C (2016) Ecology of salmonids in estuaries around the world: adaptations, habitats, and conservation. UBC Press, Vancouver

Limburg KE, Landergren P, Westin L, Elfman M, Kristiansson P (2001) Flexible modes of anadromy in Baltic sea trout: making the most of marginal spawning streams. J Fish Biol 59:682-695

Mo TA, Thorstad EB, Sandlund OT, Berntsen HH, Fiske P, Uglem I (2018) The pink salmon invasion: a Norwegian perspective. J Fish Biol 93:5-7

Mork J, Heggberget TG (1984) Eggs of Atlantic salmon (Salmo salar $\mathrm{L}$ ) and trout (S. trutta L); identification by phosphoglucoisomerase zymograms. Aquacult Res 15:59-65

Peiman KS, Birnie-Gauvin K, Larsen MH, Colborne SF, Gilmour KM, Aarestrup K et al (2017) Morphological, physiological and dietary covariation in migratory and resident adult brown trout (Salmo trutta). Zoology 123:79-90
Rubin J-F (1994) Survival and development of sea trout, Salmo trutta (L.), eggs in Baltic seawater. Fish Res 20:1-12

Salo EO (1991) Life history of Chum salmon (Oncorhynchus keta). In: C. Groot and L. Margolis (editors). Pacific Salmon Life History. UBC press, University of British Columbia, Vancouver

Saunders RL, Schom CB (1985) Importance of the variation in life history parameters of Atlantic salmon (Salmo salar). Can J Fish Aquat Sci 42:615-618

Sopinka NM, Hinch SG, Middleton CT, Hills JA, Patterson DA (2014) Mother knows best, even when stressed? Effects of maternal exposure to a stressor on offspring performance at different life stages in a wild semelparous fish. Oecologia 175:493-500

Titus RG, Mosegaard H (1992) Fluctuating recruitment and variable life history of migratory brown trout, Salmo trutta L., in a small, unstable stream. J Fish Biol 41:239-255

Vuorinen J, Piironen J (1984) Electrophoretic identification of Atlantic salmon (Salmo salar), brown trout (S. trutta), and their hybrids. Can J Fish Aquat Sci 41:1834-1837

Publisher's note Springer Nature remains neutral with regard to jurisdictional claims in published maps and institutional affiliations. 